\section{ЗАРУБІНСБКА}

Ірина Борисівна irenazar2011@gmail.com

\title{
PROVIDING THE AVIATION INDUSTRY WITH HIGHLY QUALIFIED PERSONNEL
}

\section{ЗАБЕЗПЕЧЕННЯ АВІАЦІЙНОЇ ГАЛУЗІ ВИСОКОКВАЛІФІКОВАНИМИ КАДРАМИ}

\author{
д.п.н., професор, Начіональний \\ авіаційний університет
}

\section{ZARUBINSKA Iryna Borysivna - Doctor of Pedagogic sciences, professor, National Aviation University}

The paper is devoted to the development of an integrated structural system model to ensure the training of highly qualified personnel for air transport. The main strategic directions of development and successful activity of National Aviation University at the present stage are determined. It is proved that the formation of the strategy involves obtaining a complete picture of the future state of the aviation industry and ways to solve existing problems. It is scientifically substantiated that the solution of this issue is possible through a detailed analysis of the components of the integrated system and the application of modern management methods.

Research work at the university is the main component of the educational process. Scientific and pedagogical workers, postgraduate students, doctoral students and a significant part of higher education students take part in conducting scientific research in these areas. Scientists of the university carry out complex research work in the most relevant areas of science and technology. The university has 17 specialized councils for the defense of doctoral and candidate dissertations in 29 specialties

The economic performance of any higher education institution directly depends on competitiveness and financial condition. In 2020 NAU took the sixth place in the ranking of the most popular institutions of higher education in Ukraine in the total number of applications. According to the number of entrants enrolled in the budget, it ranks fifth in Ukraine and third in the capital

For the professional development of the aviation industry, due to modern economic and social conditions, it is necessary to increase the demand for technical specialties. Training specialists for professional activities in the context of European integration requires the search for extraordinary ways to organize the educational process. Already today we have a big problem of lack of future engineers for aviation.

$$
* * *
$$

Статтю присвячено розробленню моделі інтегрованої структурної системи для забезпечення підготовки висококваліфікованих кадрів для повітряного транспорту. Визначено основні стратегічні напрямки розвитку та успішної діяльності Національного авіаційного університету на сучасному етапі. Доведено, изо формування стратегї передбачає отримання повної картини майбутнього стану авіаційної галузі та иляхів вирішення існуючих проблем. Науково обтрунтовано, ияо вирішення иььго питання можливо шляхом детального аналізу компонентів інтегрованої системи та застосування сучасних методів управління.

Науково-дослідна робота в університеті є основною складовою навчального процесу. У проведенні наукових досліджень у изи галузях беруть участь науково-педагогічні працівники, аспіранти, докторанти та значна частина студентів вищих навчальних закладів. Вчені університету проводять комплексні науково-дослідні роботи в найбільи актуальних галузях науки і техніки.

В університеті діє 17 спеиіалізованих рад із захисту докторських та кандидатських дисертаиій за 29 спеичіальностями. Економічні показники діяльності будь-якого вищого навчального закладу безпосередньо залежать від конкурентоспроможності та фінансового стану. У 2020 р. НАУ посів шосте місие в рейтингу найпопулярніших вищих навчальних закладів Украйни за загальною кількістю заявок. За кількістю абітурієнтів, зарахованих до бюджету, він посідає $п$ 'яте місие в Україні та третє в столиці.

Для професійного розвитку авіачійної галузі через сучасні економічні та сочіальні умови необхідно збільшити попит на технічні спечіальності. Підготовка фахівців для професійної діяльності у контексті європейської інтеграції вимагає поиуку надзвичайних иляхів організачії навчального процесу. Бо вже сьогодні ми маємо велику проблему відсутності майбутніх інженерів для авіації.

Keywords: aviation industry, rating, training, management, integrated structural system

Ключові слова: авіаційна галузь, рейтинг, підготовка кадрів, менеджмент, інтегрована структурна система

\section{INTRODUCTION}

At all stages of human development, the transport complex has been and will remain one of the largest "donors" of the state budget, pension fund, local budgets and extra-budgetary funds, which form the economic potential of the country. Its importance is especially important now, in the general crisis in the country.

According to the rating of the State Fiscal Service of Ukraine, the three largest taxpayers, after the energy sector and the agricultural sector, included transport companies with a total paid amount of UAH 17.9 bln.
Most taxes were paid by: the state monopolist PJSC "Ukrzaliznytsia", SE "Administration of Seaports of Ukraine" and SE "Boryspil International Airport" [1].

\section{Unresolved issues in the researched problem}

Success in the economic activity of the transport complex largely depends on the availability of scientific potential in the structure of any mode of transport, engaged in the development of economically sound investment programs, infrastructure development, business results, and more. And these issues will largely depend on what scientific potential our country has today and 
more importantly - how it will change in quantitative, structural and qualitative terms in the future for $15-20$ years.

In connection with the above, we consider it necessary to justify model of an integrated structural system to ensure the training of highly qualified personnel for air transport and to offer best practices for its implementation at National Aviation University.

The PURPOSE of the paper is the development of an integrated structural system models to ensure the training of highly qualified personnel for air transport.

\section{RESULTS}

Today, Ukraine's air transport and related ground infrastructure, which, as of January 1, 2020, 18 domestic airlines, 19 airports and airfields of civil aviation and SE "Ukraerorukh", have a significant impact on the development of the passenger market, trade and economy of the country [3] and need highly professional and competitive personnel.

National Aviation University (NAU) is one of the most powerful and famous aviation institutions in the world, which was established in 1933 as a result of the Kyiv Polytechnic Institute split, and over the years has trained more than 200,000 highly qualified personnel, about 5,000 candidates and doctors sciences for many sectors of the economy of our state, as well as more than 150 countries. Among them are well-known scientists, teachers, managers of various companies, enterprises, organizations, institutions [2].

For the aviation industry, competent professionals with an innovative systemic type of thinking, an innovative culture and the ability to innovate are required. As a result of the strategic analysis of the university, the priority strategic objectives of its development are proposed, which are presented on Fig. 1.

Highly educated people today are called intellectuals or professionals. Modern domestic higher education teaches, develops abilities, gives knowledge, forms skills, prepares for professional activity [7].

It is scientifically substantiated that the urgent issue at the present stage is the creation of a new model of an integrated structural system to ensure the training of highly qualified personnel for air transport (hereinafter ISSETHQPAT). This model includes four main components of an integrated structural system: economic, organizational, technical and technological (Fig. 2).

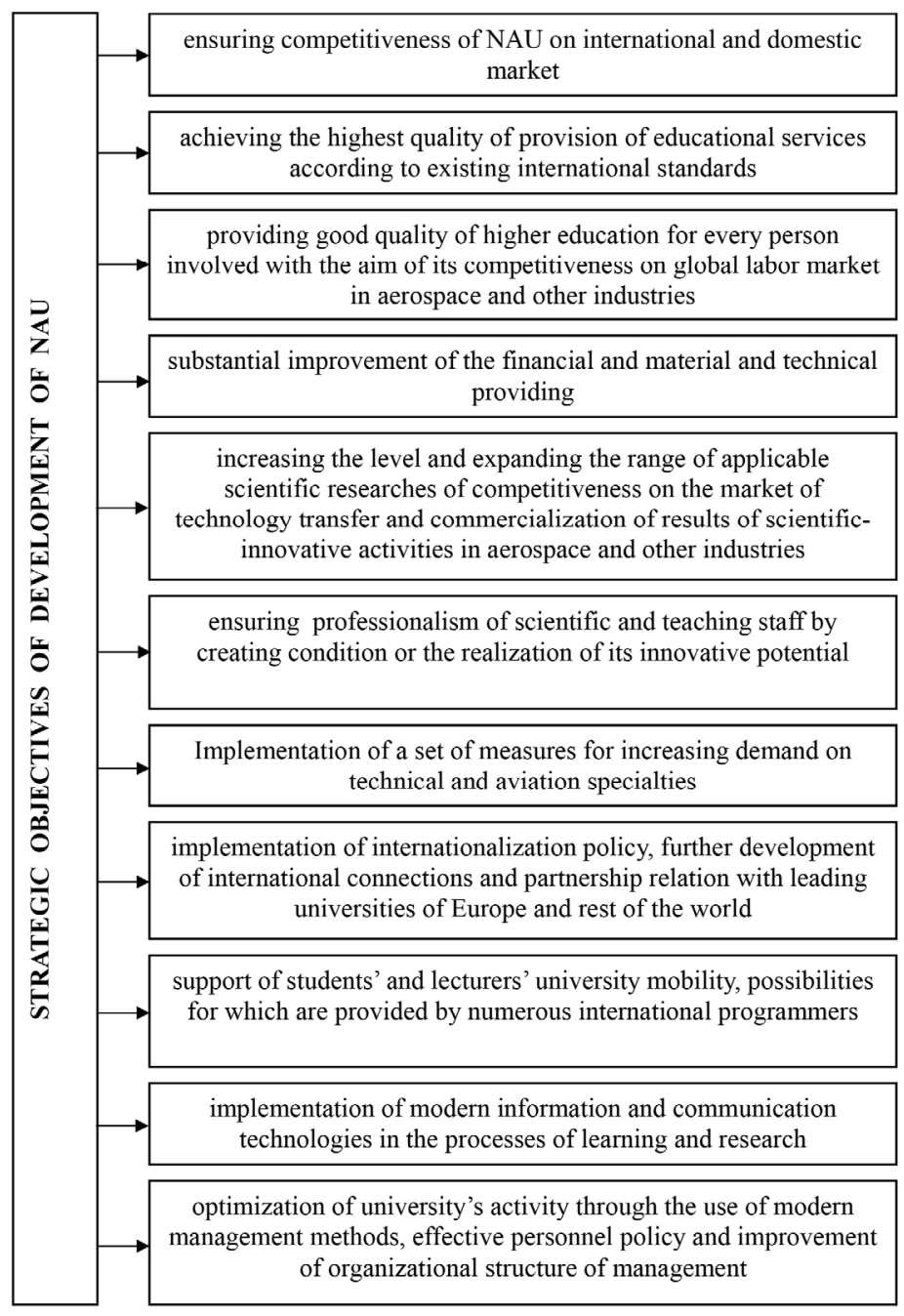

Fig. 1. Strategic objectives for further development of $N A U$ 


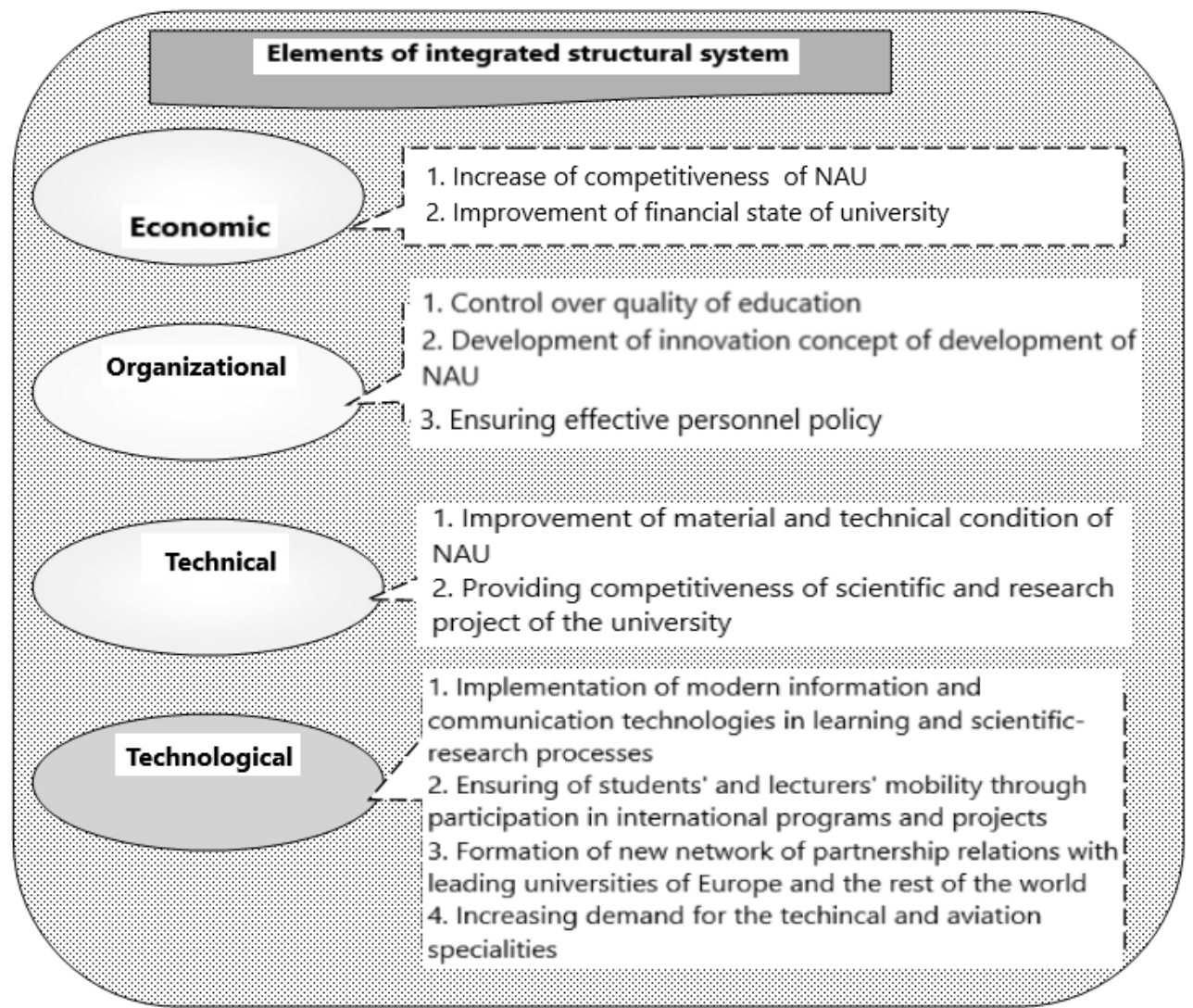

Fig. 2. Components of an integrated structural system to ensure the training of highly qualified personnel for air transport

The modern integrated structural system of providing training of highly qualified personnel for air transport is a complex multilevel functional system, the end result of which is the formation of a scientific core of professionnals for the state economy. The effective activity of transport specialists will be aimed at obtaining the maximum profit from air transportation by reducing costs while maximally meeting the needs of passengers and their efficient service.

The economic performance of any higher education institution directly depends on competitiveness and financial condition. In 2020 NAU took the sixth place in the ranking of the most popular institutions of higher education in Ukraine in the total number of applications. According to the number of entrants enrolled in the budget, it ranks fifth in Ukraine and third in the capital [2].

In 2008 the university received a Certificate of Conformity of its quality management system for educational services and research to the international quality standard ISO 9001: 2008.

To increase the competitiveness of the university in 27 of its specialties, disciplines are taught exclusively in a foreign language. The university may form separate groups for foreign citizens, stateless persons who wish to obtain higher education at the expense of individuals or legal entities, or develop individual programs. In the 2020-2021 academic year, about 1,600 students study in English, including 200 foreigners from abroad, namely: from Iran, Nigeria, Morocco, Palestine, Cote d'Ivoire, Sudan, Ecuador, Algeria, Libya, Iraq, Egypt, Turkey, etc. The teaching process in English is carried out by 312 highly qualified teachers, including 49 professors and 168 associate pro- fessors, and all of them have recognized B2 certificates of proficiency in a foreign language.

The technical component is also an integral part of the structural system to ensure the training of highly qualified personnel for the aviation industry [6]. It should be based on a European approach to innovative development, which includes the implementation of research results in the educational process. Strategic directions of development of scientific activity in NAU are shown on Fig. 3.

Research work at the university is the main component of the educational process. Scientific and pedagogical workers, post-graduate students, doctoral students, and a significant part of higher education students take part in conducting scientific research in these areas. Scientists of the university carry out complex research work in the most relevant areas of science and technology. The university has 17 specialized councils for the defense of doctoral and candidate dissertations in 29 specialties.

The presence of highly qualified personnel in NAU forms the degree of necessity, urgency of development, study, development and practical implementation of modern information and communication technologies in education. Currently, training for the aviation industry is provided by about 400 doctors of sciences, professors, and more than 700 candidates of sciences, associate professors. Among them are honored educators, honored transport workers, honored inventors, lawyers, architects, machine builders [2].

As incentives for young scientists should be provided not only targeted, but also targeted graduate and doctoral studies to train highly qualified specialists, especially for air transport, creating the most favorable conditions for applicants for degrees. 


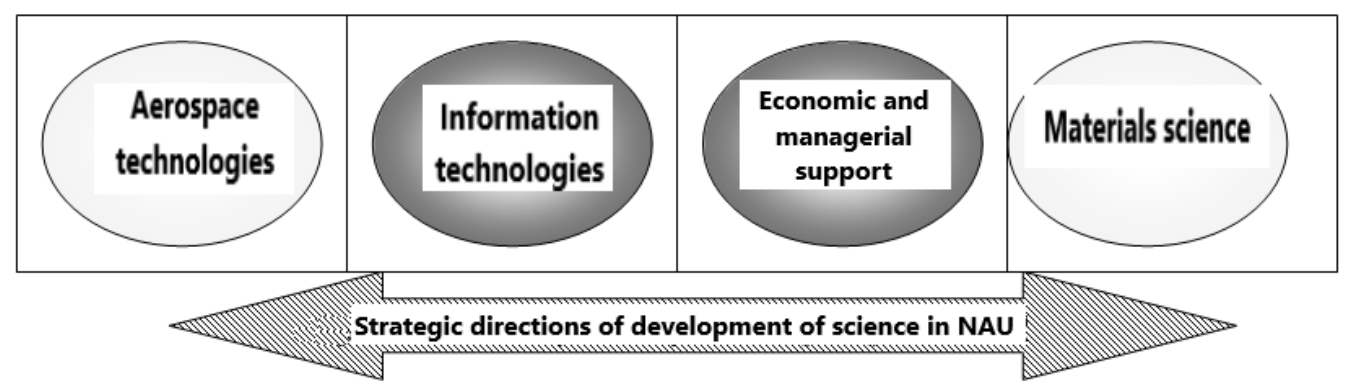

Fig. 3. Strategic directions of development of scientific activity in NAU

It is obvious that the training process should have certain priorities for regulation by the leadership of the Ministry of Education and Science of Ukraine and the Ministry of Infrastructure of Ukraine not only in terms of quality, but also in structural aspects of certain specialties by mode of transport. Obviously, if such a structural-rating analysis is performed in technical fields, we will find significant disparities in comparison with economic specialties.

For the professional development of the aviation industry, due to modern economic and social conditions, it is necessary to increase the demand for technical specialties. Training specialists for professional activities in the context of European integration requires the search for extraordinary ways to organize the educational process. Already today we have a big problem of lack of future engineers for aviation [3].

Now, for reliable operation models of an integrated structural system to ensure the training of highly qualified personnel for air transport, it is necessary to provide for the technical and technological components.

Today's level of human development dictates the training of students based on the use of modern highly effective communications. The use of computers in the educational process is in the following areas: multimedia technology is provided by the presence of certain technical (hardware) devices: computer (laptop), audio device (dynamics), monitor; interactive whiteboard - a touch interactive screen that connects to a computer. The university has also developed and implemented the concept of its integration with the world educational and scientific space with careful preservation of all achievements and traditions developed by many generations of students and staff.

In the conditions of market relations, the efficiency of the aviation industry significantly depends on the functioning of this model of an integrated structural training system. It is a set of coordinated measures aimed at achieving a specific goal. This set includes theoretical and practical issues of university management, in the first place, as well as the formation of a new network of partnerships with leading universities in Europe and the world and the development of a long-term concept for the development of NAU.

Entry of the university into the world scientific and technical community is carried out through: contacts with international foundations, participation in international programs, bilateral and multilateral agreements with foreign higher education institutions, training centers, associations and firms. Today, NAU partners are more than a hundred universities and organizations from almost 40 countries working together in the areas of academic integrity, mobility of students and researchers, interactive learning, improving and quality control of education, participation in joint cultural projects, etc. [4, 5].

The strategic development of any higher education institution is not possible without its concept. It is an organizational component of the integrated model of the IPCC. The concept of innovative development of NAU is to form a common system vision of modern innovation mission in the European and global innovation and technological dimensions, identification of strengths and weaknesses, adequate principles and priorities, "tree of goals" of the Strategy of innovative development of NAU and its structural units with branch, academic, scientific institutions, industrial complexes.

One of the crucial elements in planning the work of the educational process is the development of measures to increase the competitiveness of NAU (Table 1).

Table 1

Strengths and weaknesses of NAU

\begin{tabular}{|c|l|}
\hline Strengths & \multicolumn{1}{|c|}{ Weak sides } \\
\hline The prestige of NAU & $\begin{array}{l}\text { Lack of mechanisms for state support of priority areas of basic and applied } \\
\text { research and innovative developments for priority areas }\end{array}$ \\
\hline Average tuition fees & $\begin{array}{l}\text { Increased competition in the market of educational services and increasing } \\
\text { access to higher education outside the country }\end{array}$ \\
\hline $\begin{array}{c}\text { Availability of unique specialized programs of } \\
\text { international cooperation }\end{array}$ & $\begin{array}{l}\text { Limited industry order for innovative developments and training of specialists } \\
\text { of innovative formation, competence }\end{array}$ \\
\hline $\begin{array}{c}\text { Openness of the university management to the } \\
\text { development and implementation of innovations }\end{array}$ & $\begin{array}{l}\text { Imperfection of intersectoral system-innovation management of the aerospace } \\
\text { industry and mechanisms of intersectoral and international innovation coope- } \\
\text { ration }\end{array}$ \\
\hline Developed student government & $\begin{array}{l}\text { Lack of educational management development programs based on the model } \\
\text { of integration of educational, innovation and project management }\end{array}$ \\
\hline
\end{tabular}


The assessment of NAU's capabilities allows to determine the future prospects for the development of higher education institutions and the aviation industry in general, in terms of training highly qualified specialists for the transport sector of the state.

\section{CONCLUSION}

Application of the proposed model of an integrated structural system to ensure the training of highly qualified personnel for air transport allows top managers of NAU to study in more detail the system of organizational, technical, technological and economic components, and apply appropriate measures to ensure the quality of the educational process. After all, management covers the process of a powerful coordination mechanism and allows each member of the team to know what to strive for. In the aviation industry there is a set of specific features that managers should take into account as much as possible in the training process.

\section{References}

1. State Fiscal Service of Ukraine. URL: http://sfs.gov.ua (in Ukrainian).

2. Expert opinions (according to the information of National Aviation University). URL: http://nau.edu.ua/site/variables/ news/2020/10 (in Ukrainian).

3. Statistical data in the field of air transport. URL: https://mtu.gov.ua/content/statistichni-dani-v-galuziaviatransportu.html (in Ukrainian).

4. Novak V., Zarubinska I. Personnel management of enterprises in the conditions of international integration. International Scientific Journal of Universities and Leadership.
2016. № 2. pp. 34-39.

5. Organizational Behavior / V. Novak et.al. CondorPublishing house, 2016. 478 p. (in Ukrainian).

6. Interaction of the airport with transport enterprises: organization and management: monograph / V.O. Novak et.al. Kyiv: NAU, 2012. 277 p. (in Ukrainian).

7. Work organization and employee involvement in Europe / D. Gallie, Y. Zhou et.al. Publications Office of the European Union, 2013. $82 \mathrm{p}$.

\section{Список використаних джерел}

1. Державна фіскальна служба України (за даними Фіскальної служби України). URL: http://sfs.gov.ua (дата звернення 10.04.2020).

2. Висновки експертів (за даними Національного авіаційного університету). URL: http://nau.edu.ua/site/variables/news/2020/10

3. Статистичні дані у галузі авіаційного транспорту (за даними Міністерства інфраструктури України) URL: https://mtu.gov.ua/content/statistichni-dani-v-galuziaviatransportu.html (дата звернення 05.05.2020).

4. Novak V., Zarubinska I. Personnel management of enterprises in the conditions of international integration. International Scientific Journal of Universities and Leadership. 2016. № 2. pp. 34-39.

5. Організаційна поведінка / В.О. Новак та ін. Київ: Видавництво Кондор, 2016. 478 с.

6. Взаємодія аеропорту 3 транспортними підприємствами: організація та управління: монографія / В.О. Новак та ін. Київ: НАУ, 2012. 277 с.

7. Work organization and employee involvement in Europe / D. Gallie, Y. Zhou, et.al. Publications Office of the European Union, 2013. $82 \mathrm{p}$. 